a "plasticizer", weakening the attraction between the protein molecules and leaving them free to curl up under the influence of thermal agitation and so cause the muscle to contract. On his return to Cambridge to take up his fellowship after the war Pryor threw himself into the proving of this hypothesis by experiment and by thermodynamic analysis. He put in an inumense amount of work, the published accounts of which are still worth reading. But in the end his theory failed to take the stage. The sliding filament model won the day.

In 1955 Mark Pryor became a tutor in his college and was later senior tutor until 1964. Then once more he became free to devote time to laboratory work. His mind was still as lively, alert and original as ever. He was determined to climb back into research. He kept before him the example of A. V. Hill, with whom he had had much friendly contact during the muscle days. And in spite of taking on heavy teaching duties for the new course of cell biology, he would surely have succeeded but for the tragic accident which brought his life to an untimely end.

\section{Mr W. C. S. Wigley}

Mr W. C. S. Wigley died in October at the ago of eighty. He made important contributions to the science of ship hydrodynamics by bringing together mathematical theory and experiment and his work is still having a profound effect on ship design.
As a scholar of Emmanuel College, Cambridge, he completed the Mathematical Tripos in 1912 with considerable distinction. After the war he joined what was known as the "Tank Department" of the National Physical Laboratory, where, for many years, he pioneered work on ship propeller design and mathematically defined hull forms for research purposes. In 1927, a paper on the mathematics of wave resistance to ships earned him a Promium of the Institution of Naval Architects and in 1941 he was awarded the Gold Medal of the institution. His work at this time led to an understanding of the action of the bulbous bow in reducing the wave resistance to a ship and to the adoption in many countries of large and strangely shaped bulb and ram bows. After 1946 he worked as a consultant to the Admiralty and the United States Navy. Many of his later studies of ship resistance and stability problems remain unpublished and are known only to those who commissioned them.

Mr Wigley became a member of the Royal Institution of Naval Architects in 1926. He was an Associate Member of the Council from 1942 and in 1967 he was elected a vice president. In the same year he was awarded the MBE.

Mr Wigley enjoyed railways and country walks and spent much time making genealogical searches of West Country church registers. He is remembered as a man of retiring disposition but of fiery and highly individual spirit too. He remained a bachelor throughout his life.

\title{
Announcements
}

\section{University News}

Professor J. E. Dowling, Johns Hopkins University School of Medicine, has been appointed professor of biology at Harvard University.

Dr A. J. Meadows has been appointed to a personal professorship of astronomy in the University of Leicester. The following appointments have been made in the University of London: Dr G. W. Bisset to the chair of pharmacology at St Thomas's Hospital Medical School; Dr M. Guter to the second chair of chemical engineering al, University College; Dr N. A. Mitchison to the Jodrell chair of zoology and comparative anatomy at University College; Professor B. R. Rabin to the chair of biochemistry at University College; Dr G. F. M. Russell to the chair of psychiatry at the Royal Free Hospital School of Medicine; Mr. G. N. Walton to the chair of nuclear technology at Imperial College; Professor M. H. F. Wilkins to the chair of biophysies at King's College; Dr R. P. Dales to the chair of zoology at Bedford College.

Dr J. D. M. Wright, University of Oxford, has been appointed professor of pure mathematics at the University of Reading.

Dr L. L. Cavalli-Sforza, director of the Institute of Genetics, University of Pavia, has been appointed professor of genetics at Stanford University School of Medicine.

Dr G. H. Giebisch has been appointed Sterling professor of physiology and Dr A. J. Solnit professor of pediatries at Yale University.

\section{Appointments}

Mr C. D. Golchester has been appointed chief scientist to Marconi Radar Systems Limited.

Dr D. J. Littler has been appointed controller of research of the Central Electricity Generating Board.
Dr G. P. Murphy has been appointed director of the Roswell Park Memorial Institute, operated by the New York State Department of Health.

The Atomic Energy Board of South Africa has been reconstituted, and now includes the following members: Mr J. W. Shilling; Dr G. S. J. Kuschke; Mr H. S. Mabin; Mr J. P. Coetzee; Mr G. J. F. Human; Dr S. M. Naudé; Dr R. L. Straszacker; Professor S. F. Dosthuizen ; Mr N. J. Uys; Mr B. G. Fourie.

\section{Miscellaneous}

Dr Pierre Deslongchamps, University of Sherbrooke, has been awarded the E. W. R. Steacie memorial fellowship for 1971-72 by the National Research Council of Canada.

The US Institute of Electrical and Electronics Engineers group award for 1970 , presented in memory of Samuel A. Talbot, has been won by Dr William S. Rhode, University of Wisconsin.

Brigadier Ralph A. Bagnold has been awarded the Penrose medal by the Geological Socioty of America, in recognition of his work on the formation and movement of sand dunes.

Applications are invited by the council of St John's College, Cambridge, for a Meres senior studentship for medical research. The Meres student must be a university graduate and must carry out his research in the University of Cambridge or nearby. The studentship is tenable for between 1 and 3 years. Further information can be obtained from the master of St John's College, Cambridge CB2 1TP.

A travelling scholarship worth $£ 300$ is offered by the Institute of Electrical and Electronics Engineers for visit(s) by a postgraduate student to foreign electrical or electronic research or manufacturing establishments. Candidates must submit a proposed programme of visits, 